研究

\title{
特性格子法に基づく流体策路の聥渡応答の解析”
}

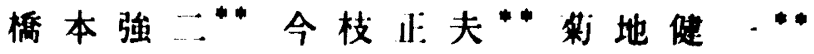

\section{The Analyses of Transient Responses of Fluid Lines by Characteristics Grid Method}

\begin{abstract}
An approach is made for the analyses of the transient responses of pneumatic and oil pipe lines. The algorithm based on the characteristics grid method considers the variations of the density, pulse wave speed and kinematic viscosity of the fluids due to the pressure changes in pipes.

The numerical results are compared with the experimental results or the ones obtained by other analytical methods for problems of this type and discussed to obtain the following conclusions: The approach is effective in predicting the transient responses of pneumatic pipe line. And also, in oil pipe lines, it obtains excellent results inclusive of the severe pressure changes due to high-pressure operation of the directional control valve.
\end{abstract}

\section{1. 緒 贯}

流体管路の動特性についての研究は, 系の解析ある いは權成的見地から非常に重要であり，見在までに厘 々の解析手法を用いた研究がなされてきている.

空気圧管路の過度度答については，C.B.Schuder ら'が一次元定常殿流を考え, 上流端の入力圧か理想 的にステップ状変化する場合について伝達関数法によ る解析を行い，また吉岡ら2)は周波数特性に基つく過 渡応答計算法を発表している。また中呞ら゙)は管内流 れが乱流の場合を考え，対流項を考虑にいれた基磁式 をすとに差分法による数値解析を行っている.

一方, 油圧管路の場合には一般に管内流れは㕌流の 場合が多く，粘性抵抗の周波数依存性を考虑にいれた

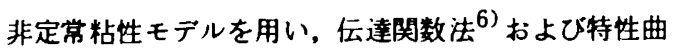

* 昭和59年 3 月 27 日 原稿受付

**徳島大学
線法古により，下流端の井急閉に伴う油現象の多く

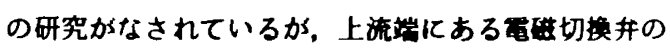

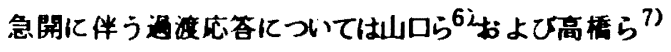
によろ研究のはか数少ないようである。 また最近の油 圧管路系は高圧条件下での使用が多くなり，高开切解 并の急開に伴う通渡応答の精度良い解折のためには管 内压の变化化伴う作動油の物性值の变化を考被にいれ ろ必要性が生ずると思われ，てのような立場からの解 析例はほとんどみあたらないようである.

本研究では, 高精度解析を目的として, 空気圧およ び油圧管路の上流端にある電喽切換并の急開に伴う過 渡芯答の問题を統一的に取扱う．数値計算には管内圧 の变化に伴う流体の物生值の变化を考虫にいれた特性 格子法 ${ }^{4)}$ 亿基づく数値計算アルゴリズム ${ }^{8)}$ を用い，単 一直管からなる供試管路を用いて数値計算した結果と 実験結果および他手法による解析結果とを比校・梌討

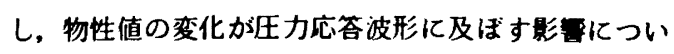
て考察する。 


\section{2. 主な町号}

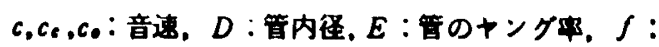

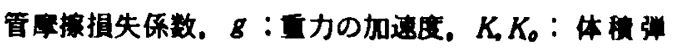

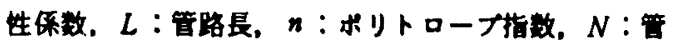

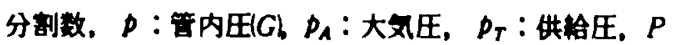

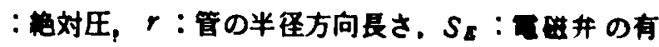

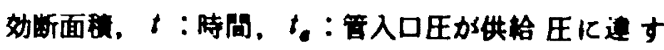
ろのに要する時間, $T$ : 空気の温度, $\boldsymbol{u}$ : 管内流违,

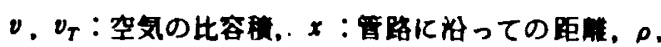

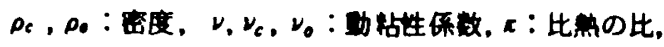

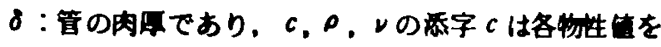

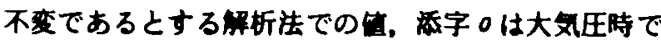
の值を意味する。

\section{3. 基硔式}

ます空気圧管路においては，空気を理想気体とみな し、解析のための基碳式として炊の各式を用いる.

速勒方程式: $p_{s}+\rho u t+\rho u u_{s}+p_{f}=0$

連梳の式: $u_{z}+\left(p_{t}+u p_{s}\right) / \rho c^{2}=0$

状悲方程式 : $P \boldsymbol{v}^{*}=$ 一定

音速の式: $c=\sqrt{n P / \rho}$

ここで, 添字 $x, t$ は何分分を意味し，式(1)中の単 位長さ当りの管摩撩損失 $p_{f}$ は管内流れを乱流とみな すと

$$
p_{f}=\rho f u|u| / 2 D
$$

である，一方，油圧管路においては式(1)。(2)を用いる か， $p_{f}$ は一次元定常首流を考える场合は式(6)、二次元 非定常粘生流れを考荿すると式(7)で表わされる。

$$
\begin{aligned}
& p_{f}=32 \rho \nu u / D^{2} \\
& p_{f}=-\rho \nu\left[\frac{\partial^{2} u}{\partial r^{2}}+\frac{1}{r} \frac{\partial u}{\partial r}\right](7)
\end{aligned}
$$

また油泹を一定とすると，作動油の圧力と密度，音 速, 輘粘性係数との関係はそれぞれ次の各式で与えら れ3?

$$
\begin{aligned}
& \rho=\rho_{0}\left(1+6.27 \times 10^{-5} p\right)(8) \\
& c=\sqrt{K / \rho} / \sqrt{1+(K / E)(D / \delta)}
\end{aligned}
$$$$
\nu=\nu_{0} \rho_{0} e^{k p / \rho}
$$

こてで, $K=K_{0}^{1}+5.3 p, k=2 \times 10^{-3} \mathrm{ca}^{2} / \mathrm{kgf}$ である.

式(3)，(4)等を用いて空気の开力と物性値との関係を 調べと, 空気圧の変化に伴い密度 $\rho$ の変化か大きい.

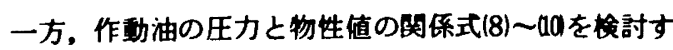

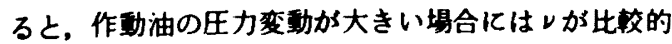
大きな変化（9.8 MPa の圧力変化でレは20\%程度変
化）を示すととかかかる.

\section{4. 效位解析}

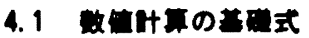

基踏式(1)。(2)は行列を用いて表わすと

$$
\mathrm{AU}_{3}+\mathrm{U}_{\mathrm{t}}=\mathrm{B}
$$

$$
\begin{aligned}
& \tau こ て,, A=\left(\begin{array}{cc}
u & 1 / \rho \\
\rho c^{2} & u
\end{array}\right), U_{x}=\left(\begin{array}{l}
u_{s} \\
p_{s}
\end{array}\right) . \\
& U_{l}=\left(\begin{array}{l}
u_{1} \\
p_{1}
\end{array}\right), \quad \mathrm{B}=\left(\begin{array}{c}
-p_{f} / \rho \\
0
\end{array}\right) .
\end{aligned}
$$

式仯の固有方程式より, 固有值 $\lambda_{1}=u+c, \lambda_{2}=$

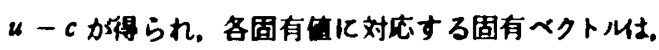
$V_{1}=\left(\begin{array}{ll}1 & 1 / \rho c\end{array}\right), V_{2}=\left(\begin{array}{ll}1 & -1 / \rho c\end{array}\right)$ である.

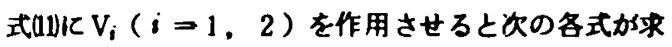
められる.

$$
\begin{array}{rr}
\frac{d x}{d t}=u+c \quad \text { arのとき } \frac{d u}{d t}+\frac{1}{\rho c} & \frac{d p}{d t}+\frac{p_{f}}{\rho} \\
& =0 \\
\frac{d x}{d t}=u-c \quad \text { 100のとき } \frac{d u}{d t}-\frac{1}{\rho c} \frac{d p}{d t}+\frac{p_{f}}{\rho} \\
& =0
\end{array}
$$

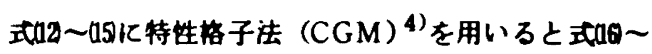
听か得られる。

$$
\begin{array}{r}
u_{p}-u_{R}+\left(p_{p}-p_{R}\right) / \rho_{R} c_{R}+p_{f_{R}}\left(t_{p}-t_{R}\right) / \rho_{R} \\
=0 \\
x_{p}-x_{R}=(u+c)_{R}\left(t_{p}-t_{R}\right) \\
u_{p}-u_{s}-\left(p_{p}-p_{s}\right) / \rho_{s} c_{s}+p_{f_{s}}\left(t_{p}-t_{s}\right) / \rho_{s} \\
=0 \\
x_{p}-x_{s}=(u-c)_{s}\left(t_{p}-t_{s}\right)
\end{array}
$$

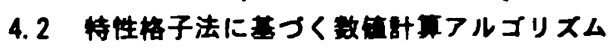
式106１99を使用し，境界条件を粗み合せると，管路 の内部点术よび境界での数值計算式が求められる. ま

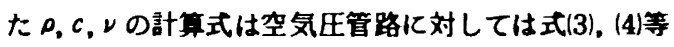
を用いて求め, 油圧管路に対しては式(8)，(9)，唋用 いる.

\section{2.1 管路の内部点}

式 177 , 19より

$$
\begin{aligned}
& t_{p}=\frac{x_{R}-x_{s}-(u+c)_{R} t_{R}+(u-c)_{s} t_{s}}{(u-c)_{s}-(u+c)_{R}} \\
& x_{p}=x_{R}+(u+c)_{R}\left(t_{p}-t_{R}\right)
\end{aligned}
$$

式16\%，182り

$$
\begin{aligned}
p_{. p}= & {\left[\left(u_{R}-u_{s}\right)+\left(p_{R} / \rho_{R} c_{R}+p_{s} / \rho_{s} c_{s}\right)-\left(t_{p}-\right.\right.} \\
& \left.\left.t_{R}\right) \cdot p_{f_{R}} / \rho_{R}+\left(t_{p}-t_{s}\right) \cdot p_{f s} / \rho_{s}\right] /(1 / \\
& \left.\rho_{R} c_{R}+1 / \rho_{s} c_{s}\right)
\end{aligned}
$$


$u_{p}=u_{R}-\left(p_{D}-p_{R}\right) / \rho_{R} c_{R}-\left(t_{p}-t_{R}\right) \cdot$

$$
p_{f_{R}} / \rho_{R}
$$

\subsection{2 塻 其}

\section{(I) 空気压管路}

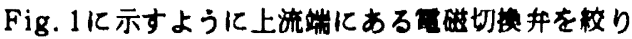

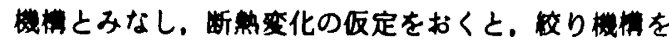

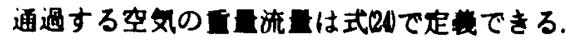

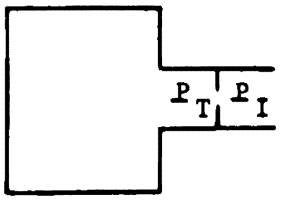

Fig.1 Orifice

$$
G_{p}=S_{P} P_{T} \sqrt{\frac{2 g}{P_{T} v_{T}}} \cdot f\left(\frac{P_{I}}{P_{T}}\right) \text { QA }
$$

ことで, $P_{I} / P_{T}=Z$ とおくと， $0 \leqq Z \leqq 0.528$ の

之き $f(Z)=\sqrt{\{\kappa /(\kappa+1)\}\{2 /(\kappa+1)\}^{2 /(x-1)}}$

$0.528 \leqq Z \leqq 1$ のとき $f(Z)=\sqrt{\{x /(x-1)\}\left\{Z^{2 / \kappa}-\right.}$

$$
\left.Z^{(\kappa+1) / \kappa}\right\}
$$

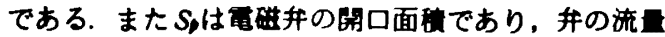
特性を直缐特性形と仮定し，定童式を求めた。

解析式：上流端では式(19)を用いて $t_{D}$ を得，式(20，180 およひ邁続の条件を組み合せて $u_{p} ， p_{p}$ の計算式を求 める．下流端では式何を用いて $t_{p}$ を得，また閉端を考 えるから $u_{p}=0$ とし，式(16より $p_{p}$ が求まる。

(II) 油圧管路

上流端では式(19)により $t_{p}$ を得． $p_{p}=p_{T} t / t_{a}(t$ $\left\langle t_{a}\right), p_{p}=p_{T}\left(t \geqq t_{a}\right)$ とし，乙の条件と式108を用 いて $u_{p}$ の計算式を得る，また下流端では空気圧管路 の場合と同じである.

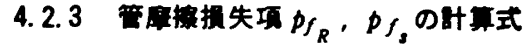

空気圧管路においては乱流とみなし，式(5)を用い， 管㕍擦損失係数 $f$ はレイノルス数の変化に対応させて 計算式を定めた。一方油压管路の場合には，一次元定 常層流を仮定すれば式(6)が用いられるが，一般に居流 流れとみなせる油圧管路内の非定常特性の解析のため には式(7)が使用される.W.Z ielke ${ }^{5)}$ は微小項である 式(1)の非線形対流項 $u u_{x}$ を省略した基礎式と式(7)を用 い, 轴対称流れに対する非定常粘性抵抗を時間領域で 計算する式を導いている．乙の非定常粘性抵抗の計算

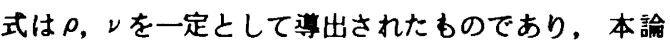

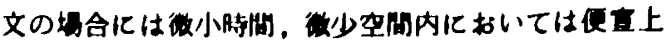

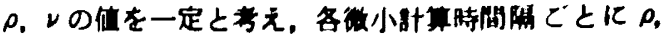

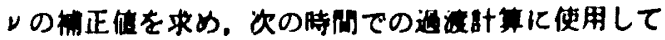
いくといった方法を探用するため，Zielke による韭

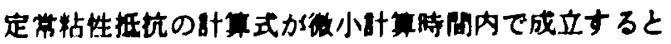
みなし、管路内部点およひ境界での数到斯式中の

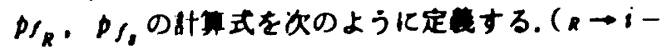

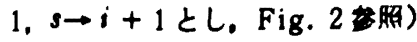

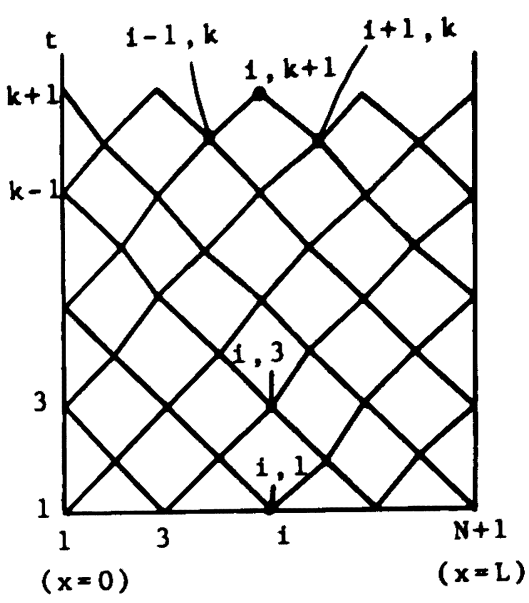

Fig. 2 Characteristics grid

$$
\begin{aligned}
& p_{f_{R}}=\frac{32 \nu_{i-1, h} \cdot \rho_{i-1, k}}{D^{2}} u_{i-1, k} \\
& +\sum_{j=1,3, \cdots}^{m}\left[\frac{16 \nu_{i-1, k-j+1}, \ldots \rho_{i-1, k-j+1}}{D^{2}} .\right. \\
& \left.\left(u_{i-1}, k-j+1-u_{i-1, k-j-1}\right) \cdot W(j \Delta t)\right] \cdots(\Delta) \\
& p_{f_{s}}=\frac{32 \nu_{i+1, k} \cdot \rho_{1+1, k}}{D^{2}} u_{i+1, k} \\
& +\sum_{j=1,3, \cdots}^{m}\left[\frac{16 \nu_{i+1}, k-j+1}{\rho_{i+1}, k-j+1} \rho^{2} .\right. \\
& \left.\left(u_{i+1, k-j+1}-u_{i+1}, k-j-1\right) \cdot W(j \Delta t)\right] \cdots
\end{aligned}
$$

ここで, 偶数内部点では式(25)， $k=3,5,7,9, \cdots, i=2,4,6, \cdots N$. , 奇数内部点では $m=k-3, k=4,6,8,10, \cdots \cdots, i=3,5,7, \cdots \cdots$, $(N-1)$. とする. 境界では $m=k-3, k=4,6,8,10, \cdots$ であり，上流端では式用用い $i=1$ ，下流端では式 (25)で $i=N+1$ とし計算式を求める.また，式(25)，(26) 
右召第 2 項中の苟面閔 $W(j \Delta t)$ は Zielkel上り

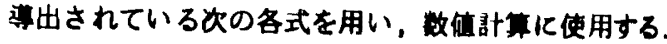
$\tau<0.02$ のとき

$$
\begin{aligned}
W(\tau)= & 0.282095 \tau^{-1 / 2}-1.250000+1.057855 \tau^{1 / 2} \\
& +0.937500 \tau+0.396696 \tau^{3 / 2}-0.351563 \tau^{2}
\end{aligned}
$$

$\tau>0.02$ のとき

$W(\tau)=e^{-26.3744 \tau}+\sigma^{-70.8493 \tau}+\sigma^{-135.0198 \tau}$

$$
+e^{-218.0216 \tau}+e^{-322.5544 \tau}
$$

ここで, $\tau=\frac{4 \nu}{D^{2}}(j \Delta t)$ であり。管路内部点では

$\nu \doteqdot\left(\nu_{i-1, k-j+1}+\nu_{i+1}, k-j+1\right) / 2$, 上流端では $\nu$ $=\nu_{2, k-j+1}$, 下流端では $\nu=\nu_{N, k-j+1}$ としは十算する.

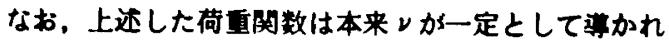
たものであり， $\nu$ が時間 $j \Delta t$ の間不変の場合に成立 するすのと考えられる. 本詥文で用いた臬みの計算法 は，物性値の変化を考慮にいれた過渡応答の解析方法 への道用のために採用したものであり．工学的な考え 万にたった近似計算手法である.

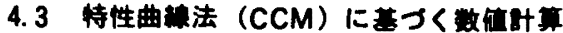

従来からよく使用されているCCMに基づく数値計 算法は，物性值の変化を考蝠にいれない規定時間間隔 方式の解析方法である。 ての方法では 4.2 で述へた CGM璂つく数值計算式中の $\rho, c, \nu$ 值を一定とし， $\Delta t=\mathrm{L} / \mathrm{c} \mathrm{N}$ 秒ごとに数值計算する.

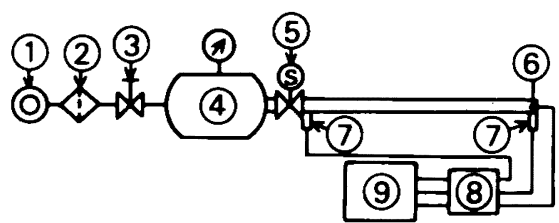
1. A1r Compressor 2. A1r Filter
3. Regulating Valve 4. Pressure Tank
5. Solenoid Valve 6. C-A Thermocouple
7. Pressure Transducer 8. Amplifier
9. Electro-magnet1c 0sc1llograph

Fig. 3 Schematic diagram of experimental setup

\section{5. 結果および考嫁}

\section{1 空気圧管路}

実検系の概略図をFig. 3 亿示す，管路には銅管（管 内径 $7.525 \mathrm{~mm}$ ) を用い，管長 $(10 \mathrm{~m}, 20 \mathrm{~m})$, 電磁升 （オリフィス径 $7 \mathrm{~mm}, 4 \mathrm{~mm})$ ）供給圧（0.147 MPa， 0.294 MPa ）を組み合せて実駼を行った。管入口，

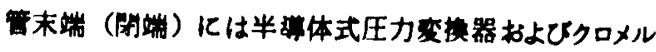

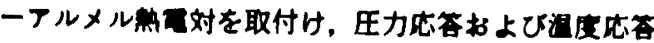

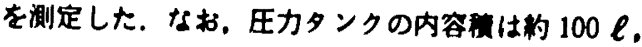

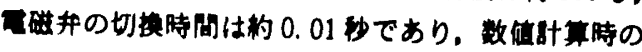
管分剖数 $N=100$ とした。

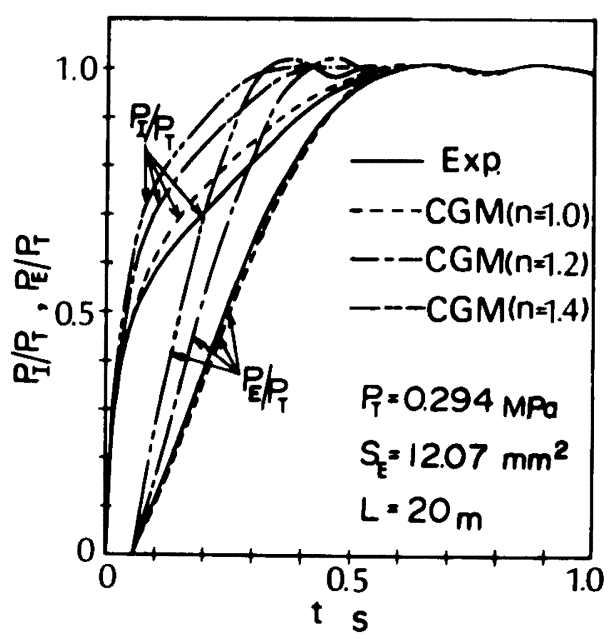

Fig.4 Traces of pressure responses

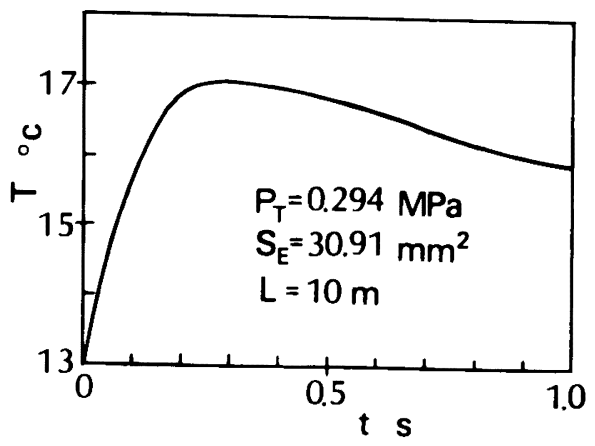

Fig.5 Transient response of temperature

Fig. 4 は供給压 $p_{T}=0.294 \mathrm{MPa}\left(3 \mathrm{kgf} / \mathrm{cm}^{2}, G\right)$ ， 䉓磁并の有勃断面䅡 $S_{E}=12.07 \mathrm{~mm}^{2}$ (オリフィス 径 4 -), 管長 $L=20 \mathrm{~m}$ の場合の管入口 $\left(p_{I} / p_{T}\right)$ およ び管末端 $\left(p_{E} / p_{T}\right)$ での過㴖応答波形である。実線 が実験結果，破線はボリトローブ指数 $n=1.0$ （等温 変化), 一点鎖線は $n=1.2$, 二点鎮線は $n=1.4$ (断 和変化）とおき, 管内流れは乱流とみなし, CGM ア ルゴリスムに基づき数値計算した結果を示す. Fig. 4 より $n=1.0$ とおき解析した結果は実験結果とよくあ っているてとがわかる. そてで，電磁并の切換に伴う 
管末端での空気温度の聥度応各を测定したとてろ。

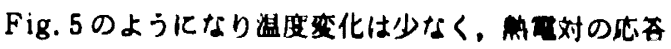

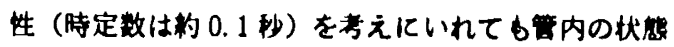
変化は等目に近いとみなしうろ。このように本研究の

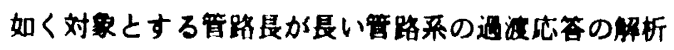

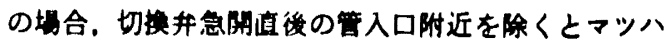
数が小さい流れであり，管壁からの然の移娌のため策 温的流较と考えてさしつかえないと䚮かかる。

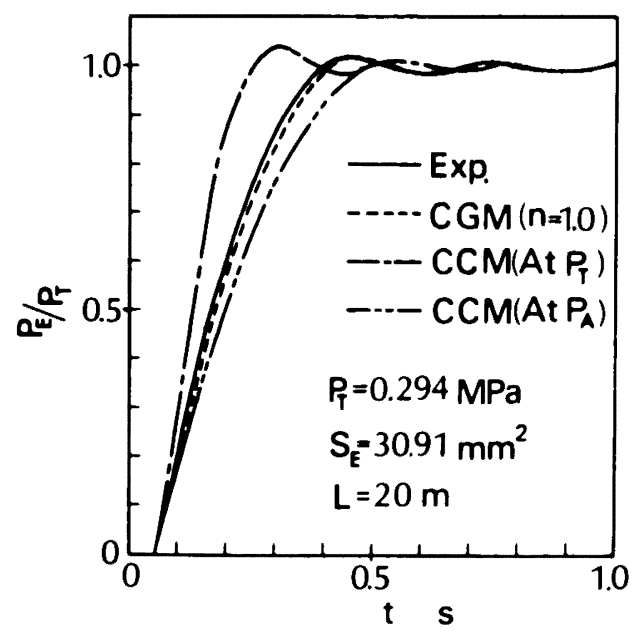

Fig. 6 Comparisons of analytical results

つぎにFig. 6 は実溆結果とC GMおよびC CMアル

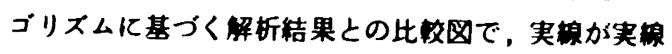

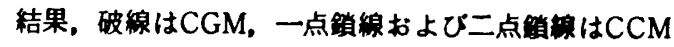
に基つく解析結果であり,一点鎮線は供給圧 $\left(p_{T}\right)$ 時 での物性値, 二点鎖線は大気圧 $\left(p_{A}\right)$ 時での物性值を 用いて計した結果を示す．Fig．6よりCCMに基つ く解析方法では管内の圧力応答を精度よく求めるこ とができないてとがかかる．との理由としては(け)。電 磁并急開直後には多量の空気加管内に流入し、管入口 附近の流速は高速で密度の変化 大きく、CCM 基つ く方法では電磁并を通り管内に流入する空気量の遇膺 变化を正磪に求められない，乙の結果管入口压の解析精 度が悪い，(iil. 管路の内部点の解析式(22)を参炤すると わかるように物性値の变化は圧力伝連特性に影管を及 ぼす.などが考えられる.またFig. 7 は $L=10 \mathrm{~m}, S_{E}$ $=12.07 \mathrm{~mm}^{2}, p_{T}=0.147 \mathrm{MPa}$ の場合の管入口およ び管末端での過渡応答波形である. ての図をみてもn $=1.0$ とおきCGMに基づき解析した䊅果は赛硢耛果 とよく一致しているてとがわかる、なお、管路が長く 管内容甶肪ある管路系の場合には，電磁并の操作に伴

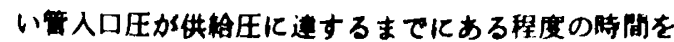

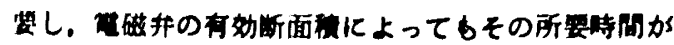
连ってくる。したかっって管人口压か理想的にステッフ

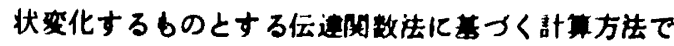

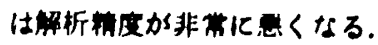

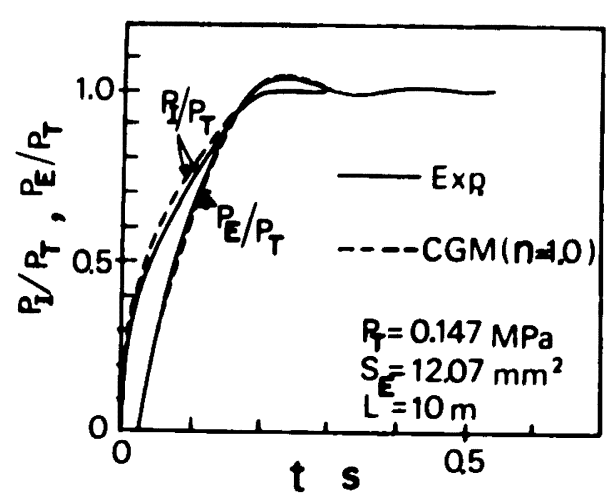

Fig.7 Traces of pressure responses

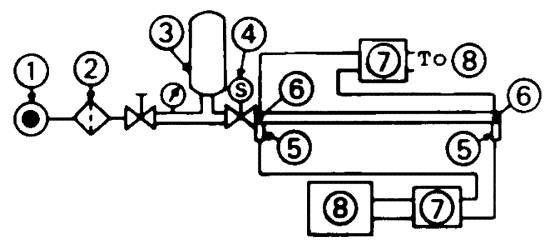

1. 011 Hydraulic Puep 2. 011 Filter

3. Accumuletor 4. Directional control valve

5. Pressure Transducer 6. C-A Theracouple

7. Amplifter 8. Osclllograph

Fig. 8 Schematic diagram of experimental setup

\section{2 油圧管路}

実蛤系の概略図をFig.8亿示す，管路には銅管（管 長 $L=9.14 \mathrm{~m}$, 管内径 $D=7.525 \mathrm{~m}$, 管の肉厚 $1 \mathrm{~m}$ ） を用い，管入口。管末端（閉端）には圧力测定用歪ゲ 一シ式圧力変換器および温度測定用クロメル・アルメ 儿熱電対を取付けてある. 使用したアキュムレータの 許容給排流全は $5 \ell / \mathrm{sec}$ であり, 作娌油（タフニ・ ハイドロックフルイド)の粘度は粘度計により測定し, 油 温は $30^{\circ} \mathrm{C}$ 亿保古実験を行った。なお，電磁并の切率に 伴う代力応答および昷度応答の测定データよりェアー レーションの発生はなく, 作動油温度の变化は殆んど 


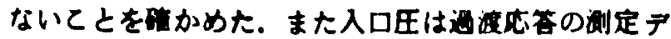

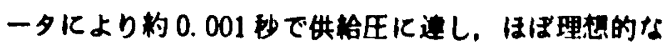
ステッフ十状入力が加えられているととが留められた。

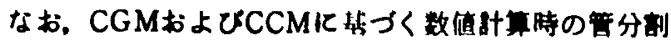
数 $N=10$ とした.

Fig. 9 はアキュムレータ内の供蛤圧 $p_{T}=9.8 \mathrm{MPa}$

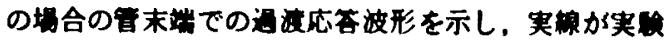

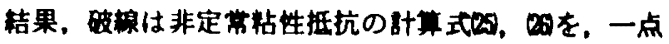
銷線は仮に一次元定常等接を表す式(6)を用い，CGM アルゴリズムに基づき数檤計萛して得られた桔果であ

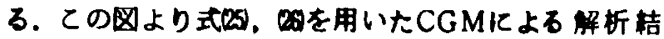

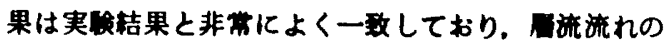
堨合は非定常粘性抵抗を考元解析すべき必要性加碚加 められる。

つぎにFig.10は式(25，26用いCGMに基づき解析 した粘果（実線で示す）と，非定营粘性抵抗を考虑し

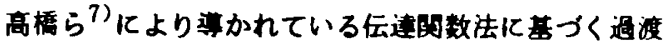
応答の計算式勿を用いて得大桔果（黒丸印および破線 で示す）との比校図であり，黒丸旫は $p=p_{T}=9.8$ $\mathrm{MPa}$,

$$
\begin{gathered}
\frac{p(t)}{p_{\mathrm{T}}} \doteqdot 1+\frac{4}{\pi} \sum_{m=1}^{M} \frac{(-1)^{m}}{2 m-1} \exp \left[-\frac{1}{2} \sqrt{\frac{\pi(2 m-1)}{\lambda}}\right. \\
\left\{1+\frac{1}{\sqrt{\lambda \pi(2 m-1)}}\right\} \tau \cdot \cos \{1- \\
\left.\sqrt{\lambda \pi(2 m-1)} \cdot \frac{1}{2}(2 m-1) \tau\right\} \\
\text { ここで, } \lambda=\left(\frac{D}{2}\right)^{2} c / \nu L, \tau=t / T, T=L / c
\end{gathered}
$$

である

破線は $p=p_{A}$ (大気圧) 時での物性値を用いて得た結 果（式句でのM=10とした）を示す．Fig.10より式27 を用い $p=p_{T}$ 時での物性値を使用して得た結果は, CGMK基づき数値計算した結果とかなりよく一致し ているが， $p=p_{A}$ 時での物性値を用いた場合には応 荅波形の減衰経過侤差が生じてくるてとがわかる。 た，Fig.11はCGMに基づく解析結果とCCMに基つく 解析結果とを比較した図で，いずれる非定常粘性抵抗 を考感にいれ，式(25)，206)用いて数値計算した結果を 示す. ての図よりCCMに基つく結果についても $p=$ $p_{A}$ 時での物性値を用いた場合には圧力の減衰 経過 亿差か生じているてとがわかる。このようにFig.10， Fig.11亿よりCGMに基づく結果を他手法による結果 と比較・検討した結果, 高圧切換并操作時などのよう に圧力変動が大きい場合には，作動油の物性値の変化

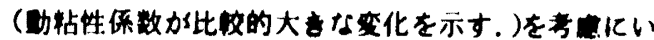

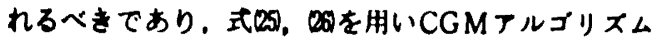

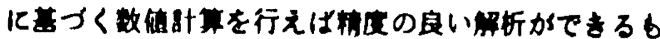
のと考えられる。

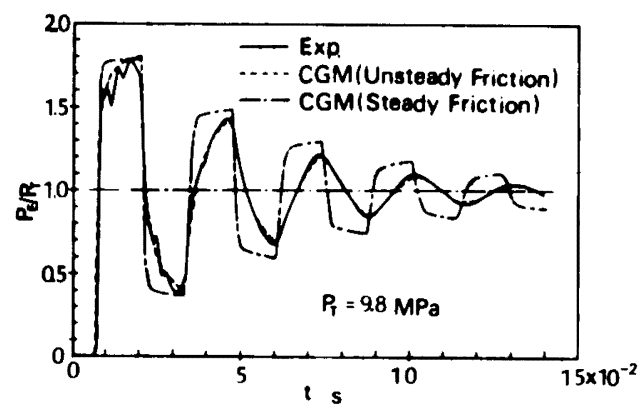

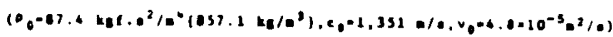

Fig. 9 Traces of pressure responses

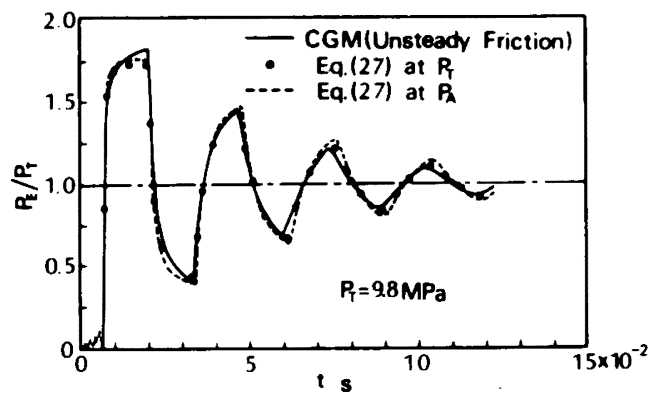

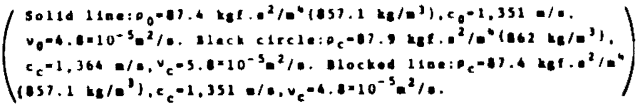

Fig. 10 Comparisons of analytical results

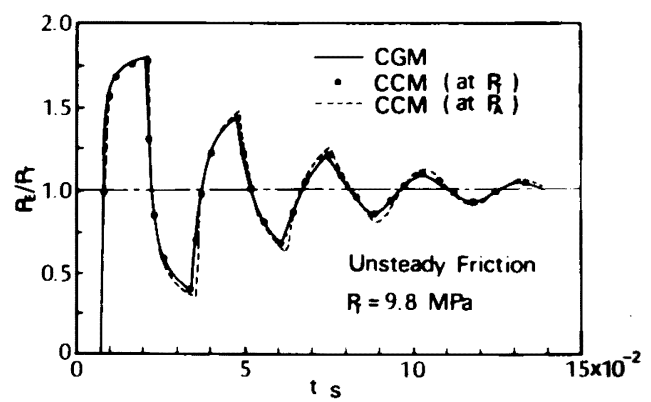

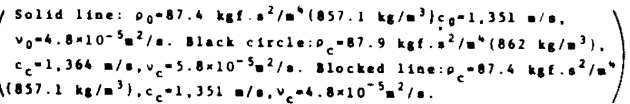

Fig. 11 Comparisons of analytical results 


\section{6. 結 日}

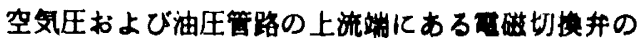

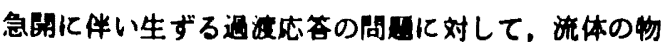

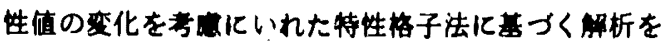
行い，実結果お。さび他手法による結果と比校・期 した桔果を要約すれば次のようになる。

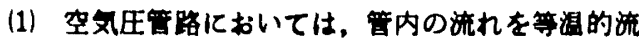

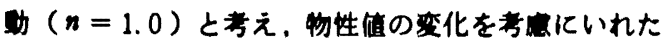

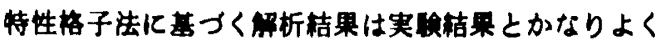
一致した．物性檤の变化を考眼にいれない手法に基つ

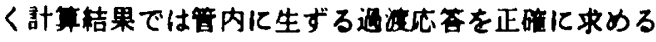
ことができない。

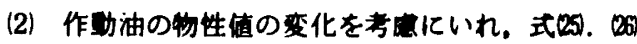
を用いた特性格子法化基づく解析結果は実路結果と 良く一致した．本手法により化力变䵢が小さい场合は

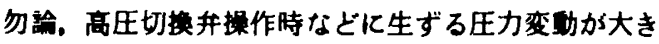
い現象を精度よく解析できる。

最後に本研究に対して鿓重な御助言をいただいた京 都大学工学部花房秀郎教投に深く期意を表します。
- 4 文

1) C.B.S chuder, R.C.B inder: The Response of Pneumatic Transmission Lines to Step Inputs, Trens. A SME. Ser.D. 81-4 $578 / 584$ ( 1959$)$

2）吉周，棵川：周波数特性化基つく流体回路系の通

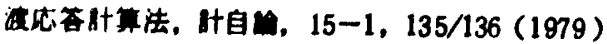

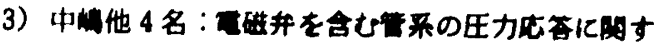
万研究，樴端，43-370，2220/2228 (1977)

4) V.L.Streeter , E.B.Wylie: Hydraulic Transients , 228, M cgraw -Hill (1967). 同

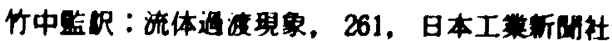
(1973)

5) W.Z ielke : Frequency-Dependent Friction in Transient Pipe Flow, Trans. ASME, Ser. D, $90-1,109 / 115$ ( 1968 )

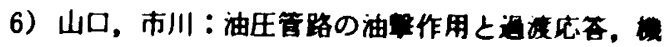
論, 38-306，321/328 (1972)

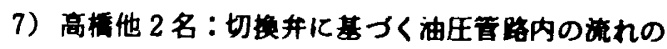
週暴見象，機詥，39-320，1261/1267（1973）

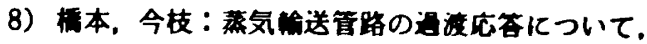
第25 回自連洲演会铪文集，375/376（1982）

9）日本油空圧学会編：油空圧便页，268，才一么社 (1975) 